\title{
Stability of Propranolol in Extemporaneously Compounded Suspensions
}

\author{
Mary H H Ensom, Jennifer Kendrick, Susan Rudolph, and Diane Decarie
}

\begin{abstract}
Background: Propranolol is a drug of choice for many diseases occurring in neonates and infants, an age group for which oral suspensions are required almost exclusively. Many adult and elderly patients for whom propranolol is prescribed are also unable to swallow solid dosage forms. In Canada, propranolol is not commercially available in a liquid dosage form, and existing recipes for extemporaneously compounded suspensions of propranolol $(1 \mathrm{mg} / \mathrm{mL})$ are limited by concerns regarding diabetes mellitus in certain subpopulations, the need for a more concentrated suspension for patients taking larger doses, and the tediousness of compounding.
\end{abstract}

Objective: To evaluate the stability of propranolol suspensions in a sugar-free, commercially available vehicle after storage at room temperature and under refrigeration for up to 120 days.

Methods: Suspensions of propranolol (2 and $5 \mathrm{mg} / \mathrm{mL}$ ) were prepared in the sugar-free vehicle (Ora-Blend SF), placed in $100-\mathrm{mL}$ amber plastic prescription bottles, and stored at $25^{\circ} \mathrm{C}$ and $4^{\circ} \mathrm{C}$. Samples were collected from each bottle once weekly for 120 days, stored frozen, and analyzed by a validated, stability-indicating high-performance liquid chromatography - ultraviolet detection method. A suspension was considered stable if it maintained at least $90 \%$ of its initial concentration of propranolol. Physical compatibility was evaluated in terms of colour, taste, precipitation, and $\mathrm{pH}$.

Results: Propranolol suspensions $2 \mathrm{mg} / \mathrm{mL}$ and $5 \mathrm{mg} / \mathrm{mL}$ stored at $25^{\circ} \mathrm{C}$ maintained at least $94.7 \%$ of their initial concentration for 120 days, and suspensions stored at $4{ }^{\circ} \mathrm{C}$ maintained at least $93.9 \%$ of their initial concentration for 120 days. There were no notable changes in $\mathrm{pH}$, and all samples remained physically unchanged except for a slight change in colour, around day 70, of suspensions stored at room temperature.

Conclusion: Propranolol suspensions ( $2 \mathrm{mg} / \mathrm{mL}$ and $5 \mathrm{mg} / \mathrm{mL}$ ) prepared in Ora-Blend SF and stored in plastic prescription bottles at either $25^{\circ} \mathrm{C}$ or $4^{\circ} \mathrm{C}$ are expected to remain stable for 120 days.

Key words: propranolol, suspension, stability

\section{RÉSUMÉ}

Contexte : Le propranolol est un médicament de choix pour de nombreuses maladies des nouveau-nés et des nourrissons, un groupe d'âge pour lequel les suspensions orales sont presque toujours requises. De nombreux patients adultes et âgés à qui l'on prescrit du propranolol sont également incapables d'avaler des formes pharmaceutiques solides. Au Canada, le propranolol n'est pas commercialisé sous forme liquide et les recettes actuelles pour les préparations extemporanées de ce médicament en suspension $(1 \mathrm{mg} / \mathrm{mL})$ sont limitées par des inquiétudes touchant le diabète sucré chez certaines sous-populations, le besoin d'une suspension plus concentrée chez les patients prenant de plus fortes doses et le long travail que nécessitent de telles préparations.

Objectif : Évaluer la stabilité de suspensions de propranolol préparées dans un excipient sans sucre disponible dans le commerce, conservées à la température ambiante et au réfrigérateur pendant un maximum de 120 jours.

Méthodes : Des suspensions de propranolol $(2 \mathrm{mg} / \mathrm{mL}$ et $5 \mathrm{mg} / \mathrm{mL})$ ont été préparées dans un excipient sans sucre (Ora-Blend SF) et conditionnées dans des flacons pour médicaments d'ordonnance en plastique ambré de $100 \mathrm{~mL}$, puis entreposées à une température de $25^{\circ} \mathrm{C}$ ou de $4{ }^{\circ} \mathrm{C}$. Des échantillons ont été prélevés de chaque flacon une fois par semaine pendant 120 jours, conservés au congélateur et analysés à l'aide d'une épreuve validée mesurant la stabilité par chromatographie liquide haute performance avec détection ultraviolette. La suspension était considérée comme stable si elle conservait au moins $90 \%$ de la concentration initiale de propranolol. La compatibilité physique a été évaluée en contrôlant tout changement dans la couleur, le goût ou le $\mathrm{pH}$ et toute formation de précipité.

Résultats : Les suspensions de propranolol à $2 \mathrm{mg} / \mathrm{mL}$ et à $5 \mathrm{mg} / \mathrm{mL}$ entreposées à une température de $25^{\circ} \mathrm{C}$ ont conservé au moins $94,7 \%$ de la concentration initiale de propranolol pendant 120 jours et les suspensions entreposées à une température de $4^{\circ} \mathrm{C}$ ont conservé au moins $93,9 \%$ de la concentration initiale de propranolol pendant 120 jours. On n'a observé aucun changement notable du $\mathrm{pH}$ et tous les échantillons ont conservé leurs propriétés physiques, à l'exception d'un léger changement de couleur, vers le $70^{\circ}$ jour, pour les suspensions entreposées à la température ambiante.

Conclusion : Les suspensions de propranolol $(2 \mathrm{mg} / \mathrm{mL}$ et $5 \mathrm{mg} / \mathrm{mL})$ préparées dans un excipient d'Ora-Blend SF, puis conditionnées dans des flacons pour médicaments d'ordonnance en plastique et entreposées à une température de $25^{\circ} \mathrm{C}$ ou de $4{ }^{\circ} \mathrm{C}$ devraient demeurer stables pendant 120 jours.

Mots clés : propranolol, suspension, stabilité

[Traduction par l'éditeur] 


\section{INTRODUCTION}

$\mathrm{M}$

ost medications taken by mouth are commercially available only in tablet or capsule form. It is not surprising, then, that many medications are not available in a dosage form suitable for children, adults, or elderly patients who are unable to swallow solid dosage forms. Furthermore, the dose of medication required by such patients may be too small to be accurately prepared by cutting the tablet. Thus, when it is impractical to use tablets or capsules, pharmacists prepare extemporaneous (or "homemade") suspensions. The amount of drug that a patient receives depends on the stability of the medication in the suspending agent, where "stability" refers to the drug remaining in its active form. Unfortunately, very little information is available on the stability of extemporaneously prepared suspensions, and different suspending agents can result in different stability profiles. Therefore, if a pharmacy interchanges vehicles, the drug may not remain stable for the anticipated shelf life, which this could lead to the patient receiving a lower dose than intended. Similarly, if the product is not properly suspended (i.e., not shaken well enough), too little of the drug may be given at the beginning of therapy and too much at the end. Most pharmacies give short expiry dates for extemporaneously prepared suspensions, such that patients or their caregivers must have prescriptions filled frequently, which leads to added costs for the health care system and inconvenience for the family.

Propranolol is a nonselective $ß$-blocker and class II antiarrhythmic agent that is used for many indications in children and adolescents, including hypertension and arrhythmias. ${ }^{1}$ It is the B-blocker of choice for (and is known to be effective in the management of children with) long QT syndrome, a condition that may cause life-threatening arrhythmias and sudden death. ${ }^{2-4}$ Propranolol is also used in children and adolescents for the treatment of akathisia, for prophylaxis of migraine, and for prevention of variceal bleeding. ${ }^{1,5-7}$ In addition, propranolol is a drug of choice for many diseases that occur primarily in neonates and infants, an age group for which suspensions are required almost exclusively. Propranolol has proven efficacy and is appropriate as first-line therapy for infantile hemangioma, the most common tumour of infancy, affecting about 1 in 10 infants. ${ }^{8-10}$ In particular, it is effective for ocular and airway hemangiomas, which can adversely affect vision and breathing, respectively. long been used in the treatment of infants with tetralogy of Fallot, a type of congenital heart disease, specifically for controlling hypercyanotic "tet" spells. ${ }^{12}$ There is now preliminary evidence for its use in preventing arrhythmias following surgical correction of tetralogy of Fallot. ${ }^{13}$ It is also a drug of choice for the treatment of supraventricular tachycardia, the most common arrhythmia of infancy. ${ }^{14}$ Usual daily doses are
2 to $5 \mathrm{mg} / \mathrm{kg}$, with larger doses (up to $8 \mathrm{mg} / \mathrm{kg}$ daily) for the treatment of arrhythmias. ${ }^{1}$

Unfortunately, in Canada, propranolol is not commercially available in a liquid dosage form. ${ }^{15}$ The only recipes and stability information on extemporaneously compounded propranolol suspensions (available at the websites of the Hospital for Sick Children ${ }^{16}$ and the Children's Hospital of Eastern Ontario, ${ }^{17}$ through the Professional Compounding Centers of America, ${ }^{18}$ and in the Calgary Health Region's pharmacy compounding manual ${ }^{19}$ ) are for a concentration of 1 $\mathrm{mg} / \mathrm{mL}$ in a simple syrup vehicle, with an expiration of 45 days. However, the sugar content in these formulations may cause concern for patients with diabetes mellitus. In addition, the existing formulations are not sufficiently concentrated for patients who need larger doses. There is also concern about providing high-osmolarity suspensions to neonates, which makes Ora-Blend SF sugar-free vehicle (Paddock Laboratories, Minnesota, MN; $1073 \mathrm{mOsm} / \mathrm{kg})^{20}$ preferable over Ora-Blend suspending vehicle (Paddock Laboratories; $2107 \mathrm{mOsm} / \mathrm{kg})^{21}$ for this population. Finally, the frequent extemporaneous preparation of suspensions can be tedious and time-consuming for pharmacy staff. Although additional stability data are available for older formulations of propranolol $1 \mathrm{mg} / \mathrm{mL}$, ${ }^{22-24}$ a search of the Embase, PubMed, and IPA databases did not yield any studies of the stability of propranolol 2 or $5 \mathrm{mg} / \mathrm{mL}$ in a sugar-free, commercially available vehicle. An informal survey of inpatient and ambulatory care pharmacists in the authors' institution, as well as pharmacists at other Canadian pediatric institutions (Alberta Children's Hospital in Calgary, Alberta; Children's Hospital in London, Ontario; The Hospital for Sick Children [SickKids] in Toronto, Ontario; IWK Health Centre in Halifax, Nova Scotia; Montreal Children's Hospital in Montréal, Quebec; Children's Hospital of Eastern Ontario in Ottawa, Ontario; and McMaster Children's Hospital in Hamilton, Ontario), pointed to the need for dosage strengths in volumes suitable for swallowing by children younger than 5 years of age $(\leq 5 \mathrm{~mL})$ and/or younger than 10 years old ( $\leq 10 \mathrm{~mL}$ ). Propranolol suspension ( 2 or $5 \mathrm{mg} / \mathrm{mL}$, appropriate for children and adults) is one of the most frequently compounded formulations for which stability data are still required.

At the authors' institution, propranolol $2 \mathrm{mg} / \mathrm{mL}$ was, until the time of this study, prepared in a methylcellulose vehicle and administered, according to historical procedures, with an arbitrary but conservative expiration date of 8 days (with refrigeration). The methylcellulose suspensions presented some major problems: high labour requirements, since the methylcellulose suspending vehicle is prepared twice weekly, taking about $2 \mathrm{~h}$ of pharmacy technician time; short expiration period, which increases the number of dispensing events for each patient, with associated increase in costs; and substantial 
inconvenience for outpatients, who can have their prescriptions filled only at the hospital's outpatient pharmacy, because very few community pharmacies have the resources or ability to compound the methylcellulose suspending base that is used in the hospital.

The objective of the current study was to evaluate the stability of propranolol suspensions $(2 \mathrm{mg} / \mathrm{mL}$ and $5 \mathrm{mg} / \mathrm{mL}$ ) in a sugar-free, commercially available vehicle (Ora-Blend SF) after storage at room temperature and under refrigeration for up to 120 days. An expected expiration period of 120 days was based on previous studies demonstrating maximum stability for propranolol $1 \mathrm{mg} / \mathrm{mL}$ suspension at a $\mathrm{pH}$ of about 3-4 (consistent with the $\mathrm{pH}$ of Ora-Blend SF, 4.2). ${ }^{20,22-24}$

\section{METHODS}

\section{Preparation of Propranolol and Set-up}

Stock suspensions of propranolol $(2 \mathrm{mg} / \mathrm{mL}$ and 5 $\mathrm{mg} / \mathrm{mL}$ ) were prepared by crushing commercially available propranolol 40-mg tablets (Apotex, Toronto, Ontario; lot JT5791, expiry February 2016) and resuspending the powder in $400 \mathrm{~mL}$ of Ora-Blend SF (Paddock Laboratories; lot 4080/A, expiry July 2013). One stock suspension (400 mL) was prepared for each concentration; six replicates of each suspension were then aliquoted into separate $100-\mathrm{mL}$ amber plastic (polyvinylchloride [PVC]) prescription bottles (Richards Packaging Inc, Richmond, British Columbia). Three bottles of each concentration were kept at room temperature $\left(25^{\circ} \mathrm{C}\right)$, and the remaining three of each concentration were refrigerated $\left(4^{\circ} \mathrm{C}\right)$.

\section{Physical Compatibility}

The physical characteristics of the suspensions were evaluated at the time of preparation and at weekly intervals up to 120 days. At each time point, the entire contents of each bottle and the sample collected from each bottle after shaking were visually examined for obvious changes in colour and odour. Each sample was also tested for changes in taste and ease of resuspension. At each time point, one (3-mL) aliquot from each bottle was collected for determination of $\mathrm{pH}$. The $\mathrm{pH}$ meter (model 8000, VWR International, Mississauga, Ontario) was calibrated at the beginning of each testing time using commercially available standards $\mathrm{pH} 7.00$ and 4.00, Fisher Scientific, Whitby, Ontario; lots 116554 and 116550, respectively; expiry November 2013 for both). Immediately after the physical observations, three $1.0-\mathrm{mL}$ samples from each storage bottle were transferred to polypropylene freezer vials (VWR International) for storage at $-85^{\circ} \mathrm{C}$ until analysis by a validated stability-indicating high pressure liquid chromatography (HPLC) - ultraviolet detection method, described below.

\section{Chemical Stability}

\section{Preparation of Stocks, Standards, and Standard Curve}

Stock suspensions of propranolol $2 \mathrm{mg} / \mathrm{mL}$ in a $50: 50$ (v:v) mixture of HPLC-grade water (Fisher Scientific; lot 116573, no expiry date) and Ora-Blend SF were prepared from propranolol powder (Sigma-Aldrich, Oakville, Ontario; lot 97H0311, no expiry date) to construct the standard curve. Metoprolol powder $1 \mathrm{mg} / \mathrm{mL}$ (Sigma-Aldrich; lot BCBB93561V, no expiry date) diluted in HPLC-grade water to a concentration of $1 \mathrm{mg} / \mathrm{mL}$ was selected as the internal standard.

The standards were prepared as follows. Propranolol 2 $\mathrm{mg} / \mathrm{mL}$ was diluted to a concentration of $0.2 \mathrm{mg} / \mathrm{mL}$ in HPLC-grade methanol (Fisher Scientific, Edmonton, Alberta; lot 117577, no expiry date) and then to a concentration of 0.1 $\mathrm{mg} / \mathrm{mL}$ in HPLC-grade water. Propranolol standard solutions containing $0.1 \mathrm{mg} / \mathrm{mL}$ of the internal standard were prepared in HPLC-grade water to final concentrations of $0.005,0.01$, $0.02,0.03,0.04$, and $0.05 \mathrm{mg} / \mathrm{mL}$. All standards were passed through a GHP (Gelman hydrophilic propylene) 13-mm diameter, $0.45-\mu \mathrm{m}$ Acrodisc microfilter (Waters Corporation, Mississauga, Ontario; lot 21770796) before injection onto the column, to prevent injection of impurities.

A 6-point calibration curve was prepared, with a blank (water) at the beginning of each run to ensure no carry-over from one run to the next. The range of this calibration curve ( 0.005 to $0.050 \mathrm{mg} / \mathrm{mL}$ ) encompassed the diluted test concentrations of propranolol $2 \mathrm{mg} / \mathrm{mL}$ and $5 \mathrm{mg} / \mathrm{mL}$. The calibration curve was generated by least-squares regression of the peak area ratio of propranolol to metoprolol and the concentration of each propranolol standard.

The precision of the assay was evaluated by intraday and interday validation methods. Intraday validation was performed by running the lowest-concentration standard and solutions of low, medium, and high concentration $(0.005,0.015,0.025$, and $0.035 \mathrm{mg} / \mathrm{mL}$, respectively) in quadruplicate throughout a single day. Interday variability was determined by running solutions of the same 4 concentrations in quadruplicate daily for 4 days. The accuracy of the assay was calculated as the mean deviation between nominal and observed concentrations. Means, standard deviations, and coefficients of variation (CVs) were calculated. Acceptable limits of the $\mathrm{CV}$ s for precision were defined a priori as less than $10 \%$, and acceptable limits for accuracy were defined as greater than $90 \%$.

\section{Preparation of Samples}

Each frozen sample was thawed and vortex-mixed for $10 \mathrm{~s}$. A $0.1-\mathrm{mL}$ aliquot of the suspension was diluted with $0.9 \mathrm{~mL}$ of HPLC-grade methanol, and the volume was adjusted to $2 \mathrm{~mL}$ with HPLC-grade water. A $0.2-\mathrm{mL}$ aliquot (for propranolol 
$2 \mathrm{mg} / \mathrm{mL}$ samples) or a $0.1-\mathrm{mL}$ aliquot (for propranolol $5 \mathrm{mg} / \mathrm{mL}$ samples) was mixed with a $0.1-\mathrm{mL}$ aliquot of metoprolol in HPLC-grade water, and the final volume was adjusted to $1 \mathrm{~mL}$ with HPLC-grade water. The final nominal propranolol concentrations were 0.020 and $0.025 \mathrm{mg} / \mathrm{mL}$, respectively. Each sample was filtered through a $0.45-\mu \mathrm{m}$ Acrodisc microfilter before a $15 \mu \mathrm{L}$-sample was withdrawn and injected onto the chromatographic column.

\section{HPLC Instrumentation}

The HPLC instrumentation (Waters Alliance System model 2690; Waters Corporation, Mississauga, Ontario) consisted of a delivery pump, an automatic injector equipped with a $200-\mu \mathrm{L}$ injector, an Atlantis $\mathrm{dC1} 184.6 \times 250 \mathrm{~mm}$ column (Waters Corporation; lot 013931346138086), an Atlantis dC18 $3.9 \times 20$ mm guard column (Waters Corporation; lot 01339313391), and an ultraviolet detector set at 212 $\mathrm{nm}$. The mobile phase consisted of a gradient mixture 50\%-10\%-50\% of methanol (Fisher Scientific, Edmonton Alberta; lots 117577 and 120511), 10\% acetonitrile (Fisher Scientific, Edmonton, Alberta; lot 117573), and a gradient mixture $40 \%-80 \%-40 \%$ of ammonium formate buffer (Sigma-Aldrich; lot BCBJ-6906V) at $\mathrm{pH} 4.0$ and room temperature. All solvents were HPLC-grade and were filtered before use. The flow rate was set at $1.5 \mathrm{~mL} / \mathrm{min}$. The assay was developed in the authors' laboratory and was based on previous work. ${ }^{20,23,25-27}$

\section{Degradation of Propranolol}

Propranolol $1 \mathrm{mg} / \mathrm{mL}$ in Ora-Blend SF was prepared from a stock solution of propranolol $5 \mathrm{mg} / \mathrm{mL}$. Aliquots of the $1 \mathrm{mg} / \mathrm{mL}$ suspension were mixed (v:v) with $2 \mathrm{~N}$ sodium hydroxide $(\mathrm{NaOH}), 2 \mathrm{~N}$ hydrochloric acid $(\mathrm{HCl})$, or $30 \%$ hydrogen peroxide $\left(\mathrm{H}_{2} \mathrm{O}_{2}\right)$, then vortex-mixed and incubated for $15 \mathrm{~min}$ at room temperature. The aliquots were then adjusted to a propranolol concentration of $0.025 \mathrm{mg} / \mathrm{mL}$ (without internal standard) using the sample-preparation method described above. Each sample was filtered and injected onto the column. The chromatogram obtained from each of the 3 degradation samples was compared with a chromatogram obtained from the calibration curve to determine any changes in concentration, retention time, and shape of the peak.

\section{Statistical Analysis}

Means, standard deviations, CVs, and accuracy were calculated for the samples analyzed. For each study day, the percentage of the original concentration of propranolol remaining was calculated. The percentage of propranolol remaining at the end of the study period was calculated from the concentration on the last day (i.e., day 120), as determined by linear regression and the concentration observed on day 0 , according to the following formula: (concentration on day $120 \div$ concentration on day 0$) \times 100 \%$. The $95 \%$ confidence interval $(\mathrm{CI})$ of the amount remaining at 120 days was calculated from the lower limit of the $95 \%$ CI of the slope of the curve relating concentration to time, via computer analysis, according to the following formula: (lower limit of the $95 \% \mathrm{CI}$ of the concentration at 120 days $\div$ concentration on day 0$) \times 100 \%$. Stability was defined as maintenance of at least $90 \%$ of the initial propranolol concentration.

\section{RESULTS}

Regression analysis of the peak area ratio of propranolol to metoprolol versus the concentration of each propranolol standard demonstrated linearity over the range of concentrations, with coefficient of determination $\left(r^{2}\right) \geq 0.999(n=4)$. The intraday and interday CVs were within acceptable limits: $1.37 \%$ and $1.71 \%$, respectively, at $0.005 \mathrm{mg} / \mathrm{mL} ; 0.72 \%$ and $3.76 \%$, respectively, at $0.015 \mathrm{mg} / \mathrm{mL} ; 0.54 \%$ and $1.11 \%$, respectively, at $0.025 \mathrm{mg} / \mathrm{mL}$; and $0.57 \%$ and $0.89 \%$, respectively, at $0.035 \mathrm{mg} / \mathrm{mL}$. The values for intraday and interday accuracy were also within acceptable limits: $96.2 \% \pm 0.98 \%$ and $96.2 \% \pm 1.71 \%$, respectively, at $0.005 \mathrm{mg} / \mathrm{mL} ; 95.8 \% \pm$ $0.64 \%$ and $97.4 \% \pm 2.56 \%$, respectively, at $0.015 \mathrm{mg} / \mathrm{mL}$; $98.9 \% \pm 0.70 \%$ and $99.0 \% \pm 1.11 \%$, respectively, at $0.025 \mathrm{mg} / \mathrm{mL}$; and $99.2 \% \pm 0.39 \%$ and $99.2 \% \pm 0.81 \%$, respectively, at $0.035 \mathrm{mg} / \mathrm{mL}$.

The retention times were $4.1 \mathrm{~min}$ for propranolol and $2.8 \mathrm{~min}$ for the internal standard (metoprolol) on day 0 (Figure $1 \mathrm{~A})$ and day 120 (Figure 1E). No interfering peaks were generated by forced degradation of propranolol with $\mathrm{HCl}$ (Figure 1B), $\mathrm{NaOH}$ (Figure 1C), or $\mathrm{H}_{2} \mathrm{O}_{2}$ (Figure 1D). In general, with degradation, the propranolol peak changed shape, shifted, and/or decreased in area relative to the original chromatogram. The HPLC method developed for this study was deemed capable of indicating stability.

There were no notable changes in $\mathrm{pH}$. Throughout the study period, the mean $\mathrm{pH}$ ( \pm standard deviation) was $4.14 \pm$ 0.088 for propranolol $2 \mathrm{mg} / \mathrm{mL}$ stored at $25^{\circ} \mathrm{C}, 4.15 \pm 0.085$ for propranolol $2 \mathrm{mg} / \mathrm{mL}$ stored at $4^{\circ} \mathrm{C}, 4.11 \pm 0.088$ for propranolol $5 \mathrm{mg} / \mathrm{mL}$ stored at $25^{\circ} \mathrm{C}$, and $4.12 \pm 0.093$ for propranolol $5 \mathrm{mg} / \mathrm{mL}$ stored at $4^{\circ} \mathrm{C}$. The green suspensions were easily resuspended throughout the study period. Around day 70 , there was a slight change in the colour of the suspensions, from green to yellowish green, for both concentrations $(2 \mathrm{mg} / \mathrm{mL}$ and $5 \mathrm{mg} / \mathrm{mL})$ stored at room temperature. There were no notable changes in the faint tart cherry taste of all suspensions.

The HPLC analysis showed that all propranolol suspensions stored at $25^{\circ} \mathrm{C}$ or $4^{\circ} \mathrm{C}$ maintained at least $90 \%$ of the original concentration for 120 days (Table 1). The lower limit of the $95 \%$ CI relating concentration to time, determined by linear regression, indicated that propranolol suspensions 

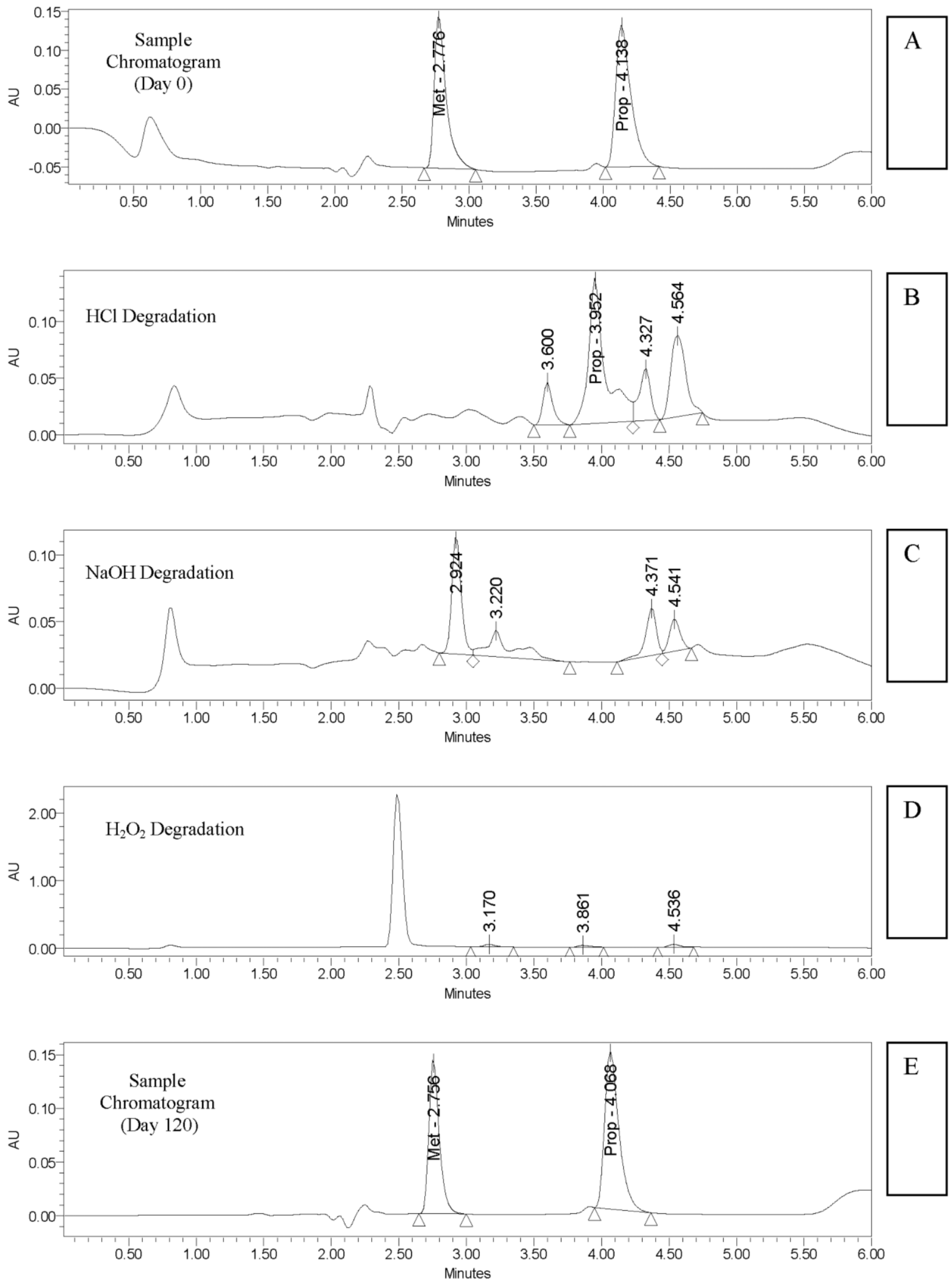

Figure 1. A: Day 0 sample with internal standard, metoprolol (Met) peak at $2.8 \mathrm{~min}$, and propranolol (Prop) peak at $4.1 \mathrm{~min}$. $B, C$, and D: Chromatograms obtained with forced degradation of propranolol with hydrochloric acid ( $\mathrm{HCl}$ ), sodium hydroxide $(\mathrm{NaOH})$, and hydrogen peroxide $\left(\mathrm{H}_{2} \mathrm{O}_{2}\right)$, respectively, showing shifting or decrease of the propranolol peak and non-interfering degradation peaks. E: Day 120 sample with internal standard, metoprolol (Met) peak at 2.8 min, and propranolol (Prop) peak at $4.1 \mathrm{~min}$. AU = arbitrary (absorbance) units. 
This single copy is for your personal, non-commercial use only.

For permission to reprint multiple copies or to order presentation-ready copies for distribution, contact CJHP at cjhpedit@cshp.ca

Table 1. Propranolol Concentration during 120 Days of Storage in Plastic Bottles at $25^{\circ} \mathrm{C}$ and $4^{\circ} \mathrm{C}$ *

\begin{tabular}{|c|c|c|c|c|}
\hline \multirow[b]{2}{*}{ Study Day } & \multicolumn{2}{|c|}{ Nominal Concentration $2.0 \mathrm{mg} / \mathrm{mL}$} & \multicolumn{2}{|c|}{ Nominal Concentration $5.0 \mathrm{mg} / \mathrm{mL}$} \\
\hline & Storage at $25^{\circ} \mathrm{C}$ & Storage at $4^{\circ} \mathrm{C}$ & Storage at $25^{\circ} \mathrm{C}$ & Storage at $4^{\circ} \mathrm{C}$ \\
\hline 0 & $2.01 \pm 0.06$ & $2.01 \pm 0.08$ & $4.99 \pm 0.07$ & $4.96 \pm 0.17$ \\
\hline 7 & $2.01 \pm 0.15 \quad(99.9)$ & $1.99 \pm 0.11 \quad(99.0)$ & $4.96 \pm 0.07 \quad(99.3)$ & $4.96 \pm 0.14 \quad(99.9)$ \\
\hline 14 & $1.98 \pm 0.03 \quad(98.4)$ & $1.99 \pm 0.04$ & $4.99 \pm 0.04 \quad(99.9)$ & $5.00 \pm 0.05(100.8)$ \\
\hline 21 & $2.03 \pm 0.06(101.2)$ & $1.99 \pm 0.05$ & $4.98 \pm 0.06(99.7)$ & $5.00 \pm 0.04(100.8)$ \\
\hline 28 & $1.98 \pm 0.08 \quad(98.8)$ & $2.00 \pm 0.03 \quad(99.7)$ & $5.00 \pm 0.04(100.1)$ & $4.98 \pm 0.04(100.3)$ \\
\hline 35 & $2.01 \pm 0.06(100.3)$ & $2.00 \pm 0.02 \quad(99.5)$ & $4.97 \pm 0.09$ (99.5) & $5.02 \pm 0.18(101.3)$ \\
\hline 42 & $2.01 \pm 0.04 \quad(99.9)$ & $2.00 \pm 0.08$ & $4.99 \pm 0.05 \quad(99.9)$ & $5.00 \pm 0.04(100.7)$ \\
\hline 49 & $2.01 \pm 0.04 \quad(99.9)$ & $1.99 \pm 0.11$ & $4.97 \pm 0.08 \quad(99.5)$ & $4.98 \pm 0.07(100.4)$ \\
\hline 56 & $1.99 \pm 0.05 \quad(99.0)$ & $1.99 \pm 0.05$ & $4.99 \pm 0.04 \quad(99.9)$ & $4.95 \pm 0.06 \quad(99.8)$ \\
\hline 63 & $1.99 \pm 0.14 \quad(99.2)$ & $1.95 \pm 0.06 \quad(97.3)$ & $4.90 \pm 0.07 \quad(98.2)$ & $4.93 \pm 0.19 \quad(99.4)$ \\
\hline 70 & $1.98 \pm 0.09$ & $1.98 \pm 0.10$ & $4.83 \pm 0.27$ & $4.86 \pm 0.46 \quad(98.0)$ \\
\hline 77 & $1.94 \pm 0.11$ & $1.86 \pm 0.07 \quad(92.7)$ & $4.94 \pm 0.09$ (99.0) & $4.90 \pm 0.12 \quad(98.8)$ \\
\hline 84 & $1.97 \pm 0.09$ & $1.97 \pm 0.14$ & $4.69 \pm 0.27$ & $4.88 \pm 0.18 \quad(98.4)$ \\
\hline 91 & $2.00 \pm 0.07$ & $1.97 \pm 0.10$ & $4.88 \pm 0.14 \quad(97.7)$ & $4.94 \pm 0.18 \quad(99.5)$ \\
\hline 98 & $1.93 \pm 0.07 \quad(96.2)$ & $1.93 \pm 0.09 \quad(96.0)$ & $4.85 \pm 0.25 \quad(97.2)$ & $4.95 \pm 0.14 \quad(99.7)$ \\
\hline 105 & $1.96 \pm 0.09 \quad(97.7)$ & $1.90 \pm 0.08 \quad(94.6)$ & $4.90 \pm 0.14 \quad(98.2)$ & $4.97 \pm 0.08(100.2)$ \\
\hline 112 & $1.98 \pm 0.09$ & $1.97 \pm 0.04$ & $4.89 \pm 0.25 \quad(97.9)$ & $4.89 \pm 0.14 \quad(98.5)$ \\
\hline 120 & $1.97 \pm 0.09 \quad(97.9)$ & $2.00 \pm 0.05 \quad(99.5)$ & $4.87 \pm 0.07 \quad(97.6)$ & $4.86 \pm 0.10 \quad(98.0)$ \\
\hline $\begin{array}{l}\% \text { remaining on day } 120 \\
\text { by linear regressiont }\end{array}$ & 97.4 & 96.9 & 96.7 & 97.8 \\
\hline $\begin{array}{l}\text { Lower limit of } 95 \% \mathrm{Cl} \text { for } \\
\% \text { remaining } \neq\end{array}$ & 95.7 & 93.9 & 94.7 & 96.6 \\
\hline
\end{tabular}

$\mathrm{Cl}=$ confidence interval.

*Data presented as mean concentration $(\mu \mathrm{g} / \mathrm{mL}) \pm$ standard deviation ( $n=3$ samples), with mean percentage remaining, relative to initial concentration, in parentheses.

+Calculated from concentration on day 120 as determined by linear regression and concentration observed on day 0 , according to the following formula: (concentration on day $120 \div$ concentration at time 0 ) $\times 100$.

$\neq$ Calculated from lower limit of $95 \% \mathrm{Cl}$ of the slope of the curve relating concentration to time, determined by linear regression, according to the following formula: (lower limit of $95 \% \mathrm{Cl}$ of concentration at day $120 \div$ concentration at time 0 ) $\times 100$.

$2 \mathrm{mg} / \mathrm{mL}$ and $5 \mathrm{mg} / \mathrm{mL}$ stored at $25^{\circ} \mathrm{C}$ maintained $95.7 \%$ and $94.7 \%$, respectively, of the initial concentration for 120 days and that propranolol suspensions $2 \mathrm{mg} / \mathrm{mL}$ and $5 \mathrm{mg} / \mathrm{mL}$ stored at $4^{\circ} \mathrm{C}$ maintained $93.9 \%$ and $96.6 \%$, respectively, of the initial concentrations for 120 days, with $95 \%$ confidence.

\section{DISCUSSION}

In the serial analysis of samples, no notable changes in taste, $\mathrm{pH}$, or ease of resuspension were observed for propranolol suspensions ( 2 and $5 \mathrm{mg} / \mathrm{mL}$ ) stored in amber plastic (PVC) bottles at $25^{\circ} \mathrm{C}$ or $4^{\circ} \mathrm{C}$ throughout the 120 -day period. There was a slight change in colour, around day 70 , of suspensions stored at room temperature. Measures of physical characteristics (other than $\mathrm{pH}$ ) were qualitative; however, all observations were documented by the same individual (D.D.) throughout the 120-day study, which eliminated interobserver bias.

According to HPLC and statistical analyses, propranolol suspensions $2 \mathrm{mg} / \mathrm{mL}$ and $5 \mathrm{mg} / \mathrm{mL}$ stored at $25^{\circ} \mathrm{C}$ maintained at least $94.7 \%$ of initial concentration for 120 days, and suspensions stored at $4^{\circ} \mathrm{C}$ maintained at least $93.9 \%$ of initial concentration for 120 days, with $95 \%$ confidence.

Before this study, the only stability data available for propranolol suspensions was for a dilute $1 \mathrm{mg} / \mathrm{mL}$ sugared formulation. At the authors' institution, compounding the more concentrated $2 \mathrm{mg} / \mathrm{mL}$ suspension in methylcellulose was laborious and had to be done frequently, because of the short expiry period. Access to both $2 \mathrm{mg} / \mathrm{mL}$ and $5 \mathrm{mg} / \mathrm{mL}$ propranolol suspensions that can be compounded with a commercially available sugar-free formulation and that have extended stability will be beneficial for the care of infants and children within the institution and in the community. These formulations will allow accurate administration of propranolol in smaller volumes and in a vehicle that is appropriate for neonates and infants. The extended stability of these formulations in Ora-Blend SF will reduce workload for compounding pharmacies and will increase convenience for families, who will not have to refill their children's prescriptions as frequently as was previously the case.

Some limitations of the current study deserve mention. All measures of physical characteristics (other than $\mathrm{pH}$ ) were qualitative, and all samples were merely visually inspected. Although these assessments were performed by an experienced individual with many years of experience in conducting stability studies, potential intraobserver bias might affect interpretation of the study results.

The results of this stability study should fill a gap in the compounding literature. This new information will have 
particular benefit for infants and children with arrhythmias, hemangiomas, and other conditions for which propranolol is the drug of choice, as well as elderly patients and others who are unable to swallow the tablet formulation of propranolol. It is important to note, however, that these data for Ora-Blend SF vehicle should not be extrapolated to Ora-Blend standard vehicle, as different vehicles may yield different propranolol stability profiles.

\section{CONCLUSION}

According to serial qualitative assessment of physical properties, $\mathrm{pH}$ measurements, and HPLC analyses, propranolol suspensions $(2 \mathrm{mg} / \mathrm{mL}$ and $5 \mathrm{mg} / \mathrm{mL}$ ) prepared in Ora-Blend $\mathrm{SF}$ and stored in amber plastic (PVC) prescription bottles at either $25^{\circ} \mathrm{C}$ or $4^{\circ} \mathrm{C}$ are expected to remain stable for 120 days.

\section{References}

1. Propranolol: drug information provided by Lexi-Comp. In: The Merck manual for health professionals. Whitehouse Station (NJ): Merck Sharp \& Dohme Corp; [updated 2013 Jan; cited 2013 Mar 14]. Available from: www.merck.com/mmpe/lexicomp/propranolol.html

2. Goldenberg I, Bradley J, Moss A, McNitt S, Polonsky S, Robinson JL, et al. Beta-blocker efficacy in high-risk patients with congenital long-QT syndrome types 1 and 2: implications for patient management. J Cardiovasc Electrophysiol. 2010;21(8):893-901.

3. Moss AJ, Zareba W, Hall WJ, Schwartz PJ, Crampton RS, Benhorin J, et al. Effectiveness and limitations of $B$-blocker therapy in congenital longQT syndrome. Circulation. 2000;101(6):616-23.

4. Villain E, Denjoy I, Lupoglazoff JM, Guicheney P, Hainque B, Lucet V, et al. Low incidence of cardiac events with ß-blocking therapy in children with long QT syndrome. Eur Heart J. 2004;25(16):1405-11.

5. Bidabadi E, Mashouf M. A randomized trial of propranolol versus sodium valproate for the prophylaxis of migraine in pediatric patients. Paediatr Drugs. 2010;12(4):269-75.

6. Kurzthaler I, Hummer M, Kohl C, Miller C, Fleischhacker WW. Propranolol treatment of olanzapine-induced akathisia. Am J Psychiatry. 1997; 154(9):1316.

7. Sökücü S, Süoglu OD, Elkabes B, Saner G. Long-term outcome after sclerotherapy with or without a beta-blocker for variceal bleeding in children. Pediatr Int. 2003;45(4):388-94.

8. Bagazgoitia L, Torrelo A, Gutiérrez JC, Hernández-Martin A, Luna P, Gutiérrez $\mathrm{M}$, et al. Propranolol for infantile hemangiomas. Pediatr Dermatol. 2011;28(2):108-14.

9. Peridis S, Pilgrim G, Athanasopoulos I, Parpounas K. A meta-analysis on the effectiveness of propranolol for the treatment of infantile airway haemangiomas. Int J Pediatr Otorhinolaryngol. 2011;75(4):455-60.

10. Zvulunov A, McCuaig C, Frieden IJ, Mancini AJ, Puttgen KB, Dohil M, et al. Oral propranolol therapy for infantile hemangiomas beyond the proliferation phase: a multicenter retrospective study. Pediatr Dermatol. 2011;28(2):94-8.

11. Missoi TG, Lueder GT, Gilbertson K, Bayliss SJ. Oral propranolol for treatment of periocular infantile hemangiomas. Arch Ophthalmol. 2011;129(7):899-903.

12. Garson A Jr, Gillette PC, McNamara DG. Propranolol: the preferred palliation for tetralogy of Fallot. Am J Cardiol. 1981;47(5):1098-104.

13. Mahmoud AB, Tantawy AE, Kouatli AA, Baslaim GM. Propranolol: a new indication for an old drug in preventing postoperative junctional ectopic tachycardia after surgical repair of tetralogy of Fallot. Interact Cardiovasc Thorac Surg. 2008;7(2):184-7.

14. Tavera MC, Bassareo PP, Neroni P, Follese C, Manca D, Montis S, et al. Supraventricular tachycardia in neonates: antiarrhythmic drug choice dilemma. J Matern Fetal Neonatal Med. 2011;24(3):541-4.

15. Propranolol. In: Drug product database. Ottawa (ON): Health Canada; [cited 2012 Oct 2]. Available from: http://webprod3.hc-sc.gc.ca/ dpd-bdpp/dispatch-repartition.do?lang=eng
16. Propranolol $\mathrm{HCl} 1 \mathrm{mg} / \mathrm{mL}$ oral suspension. Toronto (ON): The Hospital for Sick Children (SickKids), Pharmacy Compounding Service; [updated 2007 Apr; cited 2012 Oct 2]. Available from: www.sickkids.ca/pdfs/ Pharmacy/2689-Propranolol.pdf

17. Propranolol $1 \mathrm{mg} / \mathrm{mL}$ suspension. Ottawa $(\mathrm{ON})$ : Children's Hospital of Eastern Ontario, Pharmacy; [revised 1992 Apr; cited 2012 Oct 2]. Available from: www.cheo.on.ca/uploads/Pharmacists/pharm_propranolol.pdf

18. Professional Compounding Centers of America [homepage]. Houston (TX): The Centers; [cited 2012 Oct 2]. Available from: www.pccarx.com/

19. Alberta Health Services Calgary and area pharmacy compounding manual. Calgary (AB): Alberta Health Services, Calgary Drug Information Pharmacy; 2011 Nov.

20. Ora-Blend ${ }^{\circledR}$ SF flavoured sugar-free oral suspending vehicle [product data sheet]. Minneapolis (MN): Paddock Laboratories, LLC; 2010 [cited 2012 Oct 2]. Available from: www.paddocklabs.com/html/products/pdf/ Ora\%20Blend\%20SF\%20Sell\%20Sheet.pdf

21. Ora-Blend ${ }^{\circledR}$ flavoured oral suspending vehicle [product data sheet] Minneapolis (MN): Paddock Laboratories, LLC; 2010 [cited 2012 Oct 2]. Available from: www.paddocklabs.com/html/products/pdf/ Ora\%20Blend\%20Sell\%20Sheet.pdf

22. Henry DW, Repta AJ, Smith FM, White SJ. Stability of propranolol hydrochloride suspension compounded from tablets. Am J Hosp Pharm. 1986;43(6):1492-5.

23. Das Gupta V, Stewart KR. Stability of propranolol hydrochloride suspension and solution compounded from injection or tablets. Am J Hosp Pharm. 1987;44(2):360-1.

24. Rooney M, Creurer I. Stability of propranolol hydrochloride suspension and solution. Am J Hosp Pharm. 1988;45(3):530-1.

25. Modamio P, Lastra CF, Montejo O, Marifio EL. Development and validation of liquid chromatography methods for the quantitation of propranolol, metoprolol, atenolol and bisoprolol: application in solution stability studies. Int J Pharm. 1996;130(1):137-40.

26. Lakshmi Narasimham YS, Barhate VD. Development and validation of stability indicating UPLC method for the simultaneous determination of beta-blockers and diuretic drugs in pharmaceutical dosage forms. J Chem Metrol. 2010;4(1):1-20.

27. Strong DK, Decarie D, Ensom MHH. Stability of levothyroxine in sodium chloride for IV administration. Can J Hosp Pharm. 2010;63(6):437-43.

Mary H H Ensom, BS(Pharm), PharmD, FASHP, FCCP, FCSHP, is Professor, Faculty of Pharmaceutical Sciences and Distinguished University Scholar, The University of British Columbia, and Clinical Pharmacy Specialist, Department of Pharmacy, Children's and Women's Health Centre of British Columbia, Vancouver, British Columbia. She is also the Editor of the CJHP.

Jennifer Kendrick, BSC(Pharm), ACPR, PharmD, is Clinical Pharmacy Specialist, Pharmacy Department, St Paul's Hospital, Vancouver, British Columbia.

Susan Rudolph, BSc(Pharm), is Pharmacy Coordinator, Pharmacy Department, Children's and Women's Health Centre of British Columbia, Vancouver, British Columbia.

Diane Decarie, BSc, is Research Consultant, Department of Pharmacy, Children's and Women's Health Centre of British Columbia, Vancouver, British Columbia.

Competing interests: None declared.

\section{Address correspondence to:}

Dr Mary H H Ensom

Pharmacy Department OB7

Children's and Women's Health Centre of British Columbia

4500 Oak Street

Vancouver BC V6H 3N1

e-mail: ensom@mail.ubc.ca

Acknowledgements: The study was supported by a 2011 CSHP Research and Education Foundation Grant. 